\title{
Marten Subnivean Access in Winter to Subnivean Prey in Yellowstone National Park
}

\author{
Stuart Sherburne — John A. Bissonette \\ Utah COOPERATIVE Fish aND WILDLIFE RESEARCH UNIT \\ UTAH STATE UNIVERSITY \\ LOGAN
}

\begin{abstract}
American marten (Martes americana) use primarily old growth coniferous habitat (Bateman 1986, Raine 1983, Soutiere 1979, Steventon and Major 1982). However, habitat use may vary by season (Steventon and Major 1982, Koehler and Hornocker 1977, Wynne and Sherburne 1984). In summer, marten use of non-forested areas to forage for fruits and berries has been documented (Soutiere 1979, Steventon and Major 1982). While there is some seasonal variation in habitat use, all authors agree that old growth is the core habitat required by marten. During winter, marten tend to remain in mature coniferous forests and will seldom cross open areas greater than $100 \mathrm{~m}$ wide (Steventon and Major 1982, Soutiere 1979). Winter appears to be the most critical period for marten survival (Zielinski et al. 1983, Buskirk 1984).

In winter, marten seem to require subnivean access for three major reasons: food, escape cover, and homeothermy. The use of subnivean access points has been well documented (Pullianen 1981, Buskirk 1984, Buskirk et al. 1989), but the mechanisms that determine the use of some access points and not others are not well understood. Certainly there is a relationship between the use of access points and CWD (coarse woody debris). Buskirk et al. (1989) found that $49 \%$ of marten resting sites and $63 \%$ of resting episodes were associated with CWD. CWD
\end{abstract}

provides structure that breaks the snow surface, providing access to the subnivean zone where marten may escape low ambient temperatures, find prey or escape from predators. Buskirk (1989) has suggested that marten use subnivean access points to reach CWD that provides insulation from the cold. Marten in Wyoming (Buskirk et al. 1989) were found to use resting (access) sites associated with CWD when ambient temperatures were coldest; therefore, use of access points can decrease the metabolic demand for maintenance of body temperature. Studies of marten activity patterns, however, have shown that marten are most active at night during the winter (Zielinski 1981, Zielinski et al. 1983, Lesink 1955) when temperatures are coldest. This strategy is not energetically beneficial from a thermoregulatory standpoint and implies that other mechanisms may contribute to access point use. Microtines are the major food item in marten diets. Additionally, marten tend to hunt on a daily basis and their activity patterns in winter tend to be nocturnal. Zielinski et al. (1983) showed a correlation between marten activity and the activity of their principle prey in California. These aspects oftheir natural history suggest a relationship between the use of subnivean access points and prey densities. The primary goal of this study is to determine if this relationship occurs. 


\section{$\downarrow \quad$ Goals AND OBJectives}

The goal of this study is to identify the variables that influence subnivean access. The objective is to examine the relationship between subnivean access and subnivean prey abundance (see methods). Specifically, I will attempt to determine if a correlation exists between used access points and the abundance of subnivean prey. If there is a positive relationship between prey densities, CWD, and access points, then marten access point use should be related to increased levels of CWD and high prey densities. This implies that either prey and or CWD are causal factors or covariates to causal factors for access point use by marten. I will determine if these relationships exist by addressing the following hypotheses.

$\mathrm{H}_{1}$ : Utilization of access points is positively correlated with subnivean prey abundance. If there is no prey at an access point, then I expect marten will not use that access point.

$\mathrm{H}_{0}$ : There is no correlation between access point use and subnivean prey abundance.

$\mathrm{H}_{2}$ : Mean prey abundance at used access points will be higher than the mean prey abundance within marten home ranges. If this is the case, it implies a positive relationship between prey and CWD and suggests a causal mechanism. Hypothesis 3 attempts to further elucidate the relationship.

$\mathrm{H}_{0}$ : There is no difference in mean prey abundance at used and random access points.

$\mathrm{H}_{3}$ : There will be a positive relationship between prey abundance and the \% cover or dispersion of CWD. I expect to find higher prey abundance at points with high levels of CWD.

$\mathrm{H}_{0}$ : There in no correlation between prey abundance and CWD.

\section{$\downarrow \quad$ Study Area}

The Canyon-Norris region of Yellowstone National Park (YNP) has been chosen as the primary study area because it contains a variety of habitat suitable for marten and also provides a suitable road network for telemetry and accessibility to marten habitat by foot. The major cover type of the area is lodgepole pine with small to moderately sized spruce-fir inclusions. Varying degrees of fire intensity created a mosaic pattern of burned, partially burned and unburned cover types. Elevation ranges from approximately $2500 \mathrm{~m}$ to $3500 \mathrm{~m}$. Temperatures rangefrom approximately $5^{\circ}(\mathrm{C})$ to $-60^{\circ}(\mathrm{C})$ in winter and $25^{\circ}(\mathrm{C})$ to $-5^{\circ}(\mathrm{C})$ in summer. Normal snow accumulation during winter is about 2 meters, making this study area ideal for investigating subnivean access point use.

\section{MethodS}

\section{HYPOTHESIS TESTS}

$\mathrm{H}_{1}$ : There is a positive correlation between access point use and subnivean prey. To determine if a correlation exists between access point use and prey abundance, I will first document use of access points versus non-use. I will then compare prey abundance at access points with prey abundance at random plots. After determining relative prey abundance at access points (sampling scheme), I will conduct a field experiment by randomly removing small mammals from half of the used access points. Trapping will be conducted continuously throughout the summer in an effort to remove all of the prey around these used access points. Because small mammal populations tend to increase during the summer (Van Vleck 1968, Myers and Krebs 1971, Sullivan 1977, Tamarin 1977), continuous trapping should remove juveniles and immigrants from adjacent areas. In order to be assured of independence between access points, a minimum distance of $200 \mathrm{~m}$ will be used. A $100 \mathrm{~m}$ grid, centered on the access point, will be used to trap out microtines. This distance will encompass a large enough area to effectively account for microtine movements. Although microtines will eventually move back into the trapped out area, recolonization should not occur until the following spring (Tamarin 1977, Myers and Krebs 1971, Van Vleck 1968). Additionally, I will trap the areas late in the fall before the first snow fall to ensure that each area has no small mammal species. 
Seed boluses will be used the following winter to monitor the extent of migration, if any, back into the trapped areas. Finally, an abbreviated trapping scheme will be conducted the following spring, comparing trapped and untrapped areas to document recolonization, if any. The remaining access points will not be trapped during the summer. Seed boluses will be placed at these points as well. If marten use access points because of higher prey densities, they should use the control points more than the trapped access points. There may be a transition period early in the winter when marten explore access points. Statistical analysis will include a G-test, logit model, and logistical regression.

$\mathrm{H}_{2}$ : Mean prey abundance at used access points will be higher than mean prey abundance at random points within marten home ranges. Random sampling plots will be selected within the home ranges of marten as described in the sampling scheme. Small mammals will be trapped on these plots and mean preyabundance for random points (see sampling scheme) compared to mean prey abundance at used access points. I expect that mean prey densities will be higher at used access points than mean prey densities for random points. Data will be based upon relative abundances of small mammals and seed bolus utilization. Results will be compared as stated above. Analysis will consist of a G-test and loglinear model. If the data meets the criteria for normal statistics, a t-test will be used as well.

$\mathrm{H}_{3}$ :There is no correlation between prey abundance and the \% cover and dispersion of CWD. Prey abundance at access points and random plots will be compared to CWD at the same points. CWD will be measured as \% cover within a $10 \mathrm{~m}$ radius of the access point or random plot. Dispersion will be measured using the point quarter method. Distances to the closest form of CWD will be averaged for access points and ransom plots. Only CWD with a diameter of $7.5 \mathrm{~cm}$ or more will be measured. Results will be averaged for random plots and access points and then compared to prey abundance. Analysis will include a G-test and analysis of variance.

\section{$\downarrow \quad$ Analysis}

Multivariate analysis techniques will be used to identify relations between the measured variables and access point utilization. Categorical interdependence methods, such as $\mathrm{G}$ square analysis and loglinear model, will be used at this point. Logit and logistic regression techniques will be used to determine if dependency relationships exist between access point use, prey density and CWD. The contingency table given below will provide the basic data structure for analysis.

\begin{tabular}{|lcc|}
\hline \multicolumn{3}{|c|}{ MARTEN USE OF ACCESS POINTS } \\
& YES & NO \\
\hline CWD LEVEL & H & $*$ \\
& M & $*$ \\
PREY DENSITY & L & $*$ \\
& 1 & $*$ \\
& 2 & $*$ \\
& 3 & $*$ \\
\hline
\end{tabular}

\section{$\downarrow \quad$ Accomplishments to Date}

The first two of four field seasons were completed January 1 through March 15 and June 4 through September 15, 1990. In this period 10 marten (8 males, 2 females) were captured and radio collared in the Canyon region of Yellowstone National Park (YNP). Approximately 200 telemetry locations were recorded during thewinter and summer periods. Habitat data were collected for 128 subnivean access points. A sub-sample (45) of these points were used to record subnivean prey abundance and levels of course woody debris (CWD); additionally, 45 random points were selected for comparison. Prey abundance and CWD data were also collected at these points. Preliminary analysis of these data has been conducted and significant relationships have been found between used access points and relative prey abundance. A significant relationship has also been found between relative prey abundance and CWD, however, no relationship has been found between access point use and CWD.

A computer program for using radio telemetry data in a GIS database has also been developed. Results should be available by the spring of 1991 . 


\section{Potential Problems}

Two major problems developed during the 1990 field season. The first problem was related to radio telemetry. Two marten, both female, slipped their collars in the early summer. No evidence of mortality was found and every effort will be made to recapture these animals in the 1991 winter season. Radio failure became a problem in mid-summer due to low battery power. This problem can only be corrected by recapturing animals and using new collars.

The second problem lies in estimating winter prey densities from summer prey estimates. An extensive literature search is continuing and some progress has been made. Additionally, a comparison of seed bolus use and prey abundance values obtained over the summer is being conducted. Analysis is not yet complete but initial indications are that this method of estimating prey abundance in winter will be effective.

\section{$\downarrow \quad$ WORK REMAINING}

In the remaining field seasons there are three major objectives. The first is to recapture and re-fit the study animals with new radio collars and obtain more access point data. The second is to test marten use of areas in which prey were removed over the summer, and therefore further explore the relationship of marten access point use to subnivean prey. The third objective is to verify prey abundance values collected over the first summer field season and to increase the sample size of seed bolus data.

Remaining data to be analyzed include habitat variables at used and random access points, seed bolus and prey abundance relationships, and home range and cover type data. Telemetry relocations will be used to determine habitat types from the park's GIS database.

\section{Literature Cited}

Bateman, M. C. 1986. Winter habitat use, food habits and home range size of the marten, Martes americana, in western Newfoundland. Can. Field-Nat. 100:58-62.

Buskirk, S. W. 1984. Seasonal use of resting sites by marten in south-central Alaska. J. Wildl. Manage. 48:950-953.
Buskirk, S. W., S. C. Forest. M. G. Raphael, and H. J. Harlow. 1989. Winter resting site ecology of marten in the central Rocky Mountains. J. Wildl. Manage. 53:191-196.

Koehler, G. M., and M. G. Hornocker. 1977. Fire effects on marten habitat in the Selway-Bitterroot Wilderness. J. Wildl. Manage. 41:500-505.

Lensink, C. A., R. O. Skoog, and J. L. Buckley. 1955. Food habits of marten in interior Alaska and their significance. J. Wildl. Manage. 19:364-368.

Myers, J. H., and C. J. Krebs. 1971. Genetic, behavioral, and reproductive attributes of dispersing field voles Microtus pennsylvanicus and Microtus ochrogaster. Ecol. Monogr. 44:53-78.

Pulliainen, E. 1981. Food and feeding habits of the pine marten in Finnish Forest Lapland in winter. Pages 580-598 in J. A. Chapman and D. Pursley, eds. Worldwide Furbearer Conference Proceedings. Baltimore, MD.

Raine, R. M. 1983. Winter habitat use and responses to snow cover of fisher and marten in southeastern Manitoba. Can. J. Zool. 65:25-34.

Soutiere, E. C. 1979. Effects of timber harvesting on marten in Maine. J. Wildl. Manage. 43:850-860.

Steventon, J. D., and J. T. Major. 1982. Marten use of a commercially clearcut forest. J. Wildl. Manage. 46:175-182.

Sullivan, T. P. 1977. Demography and dispersal in island and mainland populations of the deer mouse, Peromyscus maniculatus. Ecology 58:964-978.

Tamarin, R. H. 1977. Dispersal in island and mainland voles. Ecology 58:1044-1054.

Van Vleck, D. B. 1968. Movements of Microtus pennsylvanicus in relation to depopulated areas. J. Mammal. 49:92-103.

Wynne, K. M., and J. A. Sherburne. 1984. Summer home range use by adult marten in northwestern Maine. Can. J. Zool. 62:941-93. 
Zielinski, W. J. 1981. Food habits, activity patterns and ectoparasites of the pine marten at Sagenen Creek, California. MS Thesis, Univ. California, Berkeley, Ca. 121 pp.

Zielinski, W. J., W. D. Spencer, and R. H. Barrett. 1983. Relationship between food habits and activity patterns of pine martens. J. Mamm. 64:387-396. 